\title{
Impact Of Repackaging On Market Share: A Case Of Cadbury Nigeria Plc And Nestle Nigeria Plc.
}

\author{
Nto, Chioma \\ Department Of Marketing, Michael Okpara University of Agriculture, Umudike, Umuahia, Nigeria.
}

\begin{abstract}
Customers judge a product by its package before buying. It is logical to say that attractive packaging is crucial to get the first time buyers to buy (Soroka, 2002 and Diana 2005). Packaging and repackaging of products help to eliminate adulteration of products from the market. This study critically evaluated the impact of repackaging on the market share volume of beverage companies in Nigeria. The hypothesis of the study was stated in null form that re-packaging activities do not have significant impact on market share expansion of companies. The study sample consisted of Cadbury Nigeria Plc and Nestle Nigeria Plc which are the two major contending firms that trade on the floor of the Nigeria stock exchange market. The major source of data was from published reports of the selected firms in the industry of study. Data were analyzed using inferential statistics (correlation and, t-test). It was discovered in the course of this study that there was no significant relationship in the market share volume of the companies (Cadbury and Nestle Nigeria PLC) between their pre and post repackaging periods. It can therefore be stated that repackaging of products those not guarantee an increase in the market share volume of companies. Based on the findings of this study, we recommend that companies should expand the market by engaging in sales promotion to create awareness on their improved brands to get more customers which can result in larger market share volume. Repackaging of product should follow the trend of technological improvement and innovations.
\end{abstract}

Key words: Repackaging, Market-share-volume, Cadbury and Nestle Nigeria Plc

\section{INTRODUCTION}

Marketing innovation is the implementation of a new marketing method involving significant changes in product design and redesign or repackaging, product placement, product promotion or pricing (OECD Oslo Manual, 2005). Marketing innovations target at addressing customer needs better, opening up new markets, or newly positioning a firm's product on the market with the intention of increasing firm's sales. Marketing innovations are strongly related to pricing strategies, product package design properties, product placement and promotion activities along the lines of four P's (Place, Product, Promotion, Price) of marketing (Kotler, 1991). Drucker (1985) defined innovation as the process of equipping in new, improved capabilities or increased utility. Products are always protected by packaging. Repackaging is not a new idea. A package is a material around the product meant to protect it from damages. It contains information about the brand, indicates the quality and how to use it. The fate of a business organization operating in a market environment is ruled by its customers. Product Repackaging is a very important marketing strategy to glamorize and modify a product in order to attract the customer's attention.

Packaging prevents spoiling and breakage, enhances convenience in use or storage, and makes product easier to identify. Repackaging could be regarded as putting or modifying a product in a form from its original form to attract or appeal to more customers. It is logical to say that attractive packaging is crucial in order to get the first time buyers to buy. Soroka (2002) opines that without attractive packaging, it would be difficult for a product to sell in a market. Your first step to enter the market is crushed if packaging is ugly or worn-out. Pilditchin (1972), simply defined "package" as "the silent sales-man". Lewis (1991) expanded further on Pilditchin's views, stating that "good packaging is far more than a Salesman, it is a flag of recognition and symbol of values". Product re-packaging as an innovation in marketing involves changing the size, shape and design of products in order to suit the firm or for consumers' convenience. Repackaging means re-casing of a product into a new packaging using boxes, bags and/or other types of containers and provides a brand new product to bring to market. Marketing strategy formulation is viewed as an antecedent to performance outcomes (Lages 2004). It is the modus operandi that allows an organization to concentrate its limited resources on the best available opportunities to increase sales and achieve a sustainable competitive advantage (Michael, et al., 2013). Market share is one of the primary indicators companies use to measure how well they are doing versus competition. Market share is the percentage of business or sales a company welds out of total business or sales by all competitors combined in any given market. Market share is the percentage of an industry or market's total sales that is earned by a particular company over a specified time period. Market share represents the percentage 
of an industry or market's total sales that is earned by a particular company over a specified time period (Ivestopedia, 2016). Market share is calculated by taking the company's sales over the period and dividing it by the total sales of the industry over the same period. This metric is used to give a general idea of the size of a company in relation to its market and its competitors. A company's market share is its portion of total sales in relation to the market it operates within. For example, if a company sells 100 million worth of beverages a year domestically, and the total market size for beverages sold in the Nigeria amounts to $\$ 500$ million, the company's Nigerian market share for beverages would be $20 \%$. Companies look at market share increases and decreases carefully, because they can be a sign of the relative competitiveness of the company's products or services. As the total market for a product or service grows, a company that is maintaining its market share is growing revenues at the same rate as the total market. A company that is growing its market share will be growing its revenues faster than its competitors. Market share increases can allow a company to improve profitability.

\section{PROBLEM STATEMENT}

Consumer market grows rapidly every year and the number of competitors among different types of products and goods increases steadily. To standout against competitors, every company tries to invent something new and to get the competitive advantage for providing the product to the end customer. One of the marketing tools that have become popular and important is product repackaging and packaging design which allows companies to be different from each other's and to have more priorities among competitors. This has become a reason why nowadays there is a big variety of design packages in the market. Consumer preferences and consumer buying behavior are the major issues that should be taken into account when designing a new package. In spite of factors such as new technology or material development, consumer's choices and desires are the important elements that drive the marketing process. Consumers are the key actors in planning and implementing packages. However, the key issue for packaging design is to understand the consumer (Stewart 2004). Shammot (2011) observed that that more value than cost can be achieved from successful repackaged designs. Mohammad et al (2012), identified that cost reduction, improved profits, improved sales can be achieved due to repackaging of products. Customer loyalty can be assured with sound packaging and repackaging of products. Sajuyigbe, et al., (2013) studied on the Impact of packaging on organizational sales turnover: a case study of Patterson Zoconist Cussons (PZ) Plc, Nigeria. He Employed Ordinary Least Squares Multiple Regression Method With The Aid Of Statistical Package For Social Science (SPSS). Result Showed That Packaging Has Significant Effect On Sales Turnover. Result Also Found That Packaging And Other Factors Such As Brand Name, Pricing And Promotion Jointly Predict Organizational Sales Turnover, Which Accounted For 98\% Variance Of Sales Turnover. The Study Concluded That A Specific Package Must Be Developed For Each Product Because Variations In Packaging Can Make A Product Saleable In Various Target Markets.Gurhan Et Al., (2013) Studied The Effects Of Innovation Types On Firm Performance. He Applied A Survey Basic Research. The Results Reveal The Positive Effects Of Innovations On Firm Performance In Manufacturing Industries. On The Same View, Mitul Et Al., (2012) Studied The Role Of Packaging On Consumer Buying Behavior-Patan. District Studied On The. The Work Is Based In Patan District Of Gujarat. The Result Relived That Package Performs An Important Role In Marketing Communications, Especially In The Point Of Sale And Could Be Treated As One Of The Most Important Factors Influencing Consumer's Purchase Decision. It Has Been Observed That One Of The Reasons For Product Repackaging Is When A Product Has Reached Its Saturation Or Maturity Stage In Its Life Cycle. Several Products In The Beverage Industry Have Reached Their Maturity Stage And Are Heading Towards Decline Stage Which Leads To Decline In Their Contributions To Market Share (Falling Market Share). This Is A Period During Which New Users Of The Product Cannot Be Added And Consumers Are No Longer Interested About The Product. Lately There Have Been A Lot Of Quality Control Scandals Accounting For Lack Of Confidence On Many Essential Commodities. Therefore, Consumers Are Crying Out For Safe Products That Will Not Affect Their Health Adversely Or That Of Their Families. There Is Problem Of High Cost Of Some Beverages, Which Has Made Pertinent The Role Of Repackaging Towards making products in small packs and, sachets that are affordable to meet the requirements of different classes of consumers. It is on this premise that the researcher wishes to evaluate the impact of repackaging on market share of some food and confectionary companies in Nigeria. In this vein, the study set out to answer the research question of: does repackaging of products have any impact on the market share of companies?

\section{OBJECTIVE OF THE STUDY}

The objective of the study was to evaluate the impact of repackaging on market share of beverage companies in Nigeria: a case study of Cadbury and Nestle Nigeria Limited. 
IV.

\section{HYPOTHESIS}

The hypothesis of the study was stated in null form.

$\mathrm{H}_{0}$ : Re-packaging activities do not have significant impact on market share expansion of companies

\section{RESEARCH METHODOLOGY}

The research design for this study took the form of time series experimental design as the performance of firms for the period before product repackaging was captured with that of post repackaging for the purpose of ascertaining the effects of repackaging of market offer in corporate performance. The major source of data was from published reports of selected firms in the industry of study. Data were analyzed using inferential statistics (correlation and, t-test). The area of study as scope is the food and confectionary industry in Nigeria, consisting of Cadbury Nig Plc and Nestle Nig Plc as two major contenders firms that trade on the floor of the Nigeria stock exchange market. Hence, the thrust of the study is Nigeria and the corporate Headquarter records of these firms. The two firms in the food product industry in Nigeria formed the population of the study. These two firms (Cadbury and Nestle Nigeria Limited) equally made up the sample size for the study. Data for the study was pulled from oral interview and from the annual records from the firms under study. The data obtained for this work were analyzed using Inferential Statistics such as Correlation and t-test.

Their formulas are below:

The Pearson correlation coefficient $\mathrm{R}$ mathematical model is represented in notation 1 given as:

$r_{x y}=\sum(\chi-\chi)(y-y)$

$$
\mathrm{nS}_{\mathrm{x}} \cdot \mathrm{S}_{\mathrm{y}}
$$

Where: $\mathrm{X}$ and $\mathrm{Y}$ are each values of variables as represented by $\mathrm{X}$ and $\mathrm{Y}$.

$\bar{X}$ and $\bar{Y}$ are mean values of $\mathrm{X}$ and $\mathrm{Y}$

$S_{x}$ and $S_{y}$ are standard deviation of $X$ and $Y$ and

$\mathrm{n}$ is the number of paired values.

The t-test statistics for Difference of mean is represented as notation 2 shown as:

$\mathrm{t}=\frac{\left(\chi_{1}^{-}-\chi_{2}\right)}{\sqrt{\mathrm{S}_{1}{ }^{2}+\mathrm{S}_{2}{ }^{2}}}$

Where,

$\bar{X}_{1}=$ mean of the first set of values

$\bar{X}_{2}=$ mean of the second set of values

$\mathrm{n}_{1}=$ sample size of the first set of values

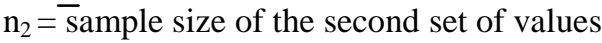

$S_{1}^{2}=$ variance $\left(S_{1}^{2}\right)$ or standard deviation $\left(\mathrm{S}_{1}\right)$ of the first set of values

$\mathrm{S}_{2}{ }^{2}=$ variance $\left(\mathrm{S}_{2}{ }^{2}\right)$ or standard deviation $\left(\mathrm{S}_{2}\right)$ of the second set of values.

\section{RESULTS AND DISCUSSION}

The analysis is billed at determining the relationship between product pre-repackaging and post-repackaging performance of companies in the food industry in Nigeria. The basis of assessment was their market share growth. They are shown in tables below:

Table 1: Market share of Cadbury and Nestle for the period pre-Repackaging of product

\begin{tabular}{lccccccc} 
Year & 1993 & 1992 & & 1991 & 1990 & 1989 \\
Cadbury & 58.85 & 58.47 & & 53.63 & 49.47 & 50.90 \\
Nestle & 31.15 & 30.53 & \multicolumn{3}{c}{32.37} & 40.53 & 36.10 \\
\multicolumn{1}{c}{70.0} & & 89.0 & & 86.0 & 90.0 & 87.0 & \\
Mean x & 45 & & 44.5 & 43 & 45 & & 43.5
\end{tabular}

Adopted from: Annual Report of Nestle Nigeria PLC and Cadbury Nigeria PLC 1989-1993

The table accounts for the market share growth of Cadbury Nigeria PLC and nestle Nigeria PLC for the period pre-product repackaging. It also shows the mean yearly market share performance of the industry as firms that operate on the floor of the Nigeria Exchange market 
Table 2: Market share structure of Cadbury and Nestle for the period post Re-packaging

\begin{tabular}{|c|c|c|c|c|c|}
\hline & \multirow{5}{*}{$\begin{array}{cc} & \text { Year } \\
& \text { Cadbury } \\
& \text { Nestle } \\
91.00 \quad & 91.00 \\
& \text { Mean x }\end{array}$} & 2007 & 2008 & 2009 & 2010 \\
\hline & & 59.50 & 59.22 & 54.85 & 49.72 \\
\hline & & 31.50 & 31.78 & 34.15 & 41.28 \\
\hline & & & 89.00 & & \\
\hline & & 45.5 & 45.5 & 44.5 & 45.5 \\
\hline
\end{tabular}

Adopted from: Annual Report of Nestle Nigeria PLC and Cadbury Nigeria PLC 2007-2011

This shows the market share growth of Cadbury Nigeria PLC and Nestle Nigeria PLC as members of the food industry in Nigeria for the period post product repackaging. The average performance of the industry par firm is also shown.

Table 3: Market share growth differential factor $(d)$

$\begin{array}{crcccc}\mathrm{b} / 4 & 45.0 & 44.5 & 43.0 & 45.0 & 43.5 \\ \text { After } & 45.5 & 45.5 & 44.5 & 45.5 & 44.5 \\ \text { Df(d) } & 0.5 & 1.0 & 1.5 & 0.5 & 1.0\end{array}$

Source; Derived from Table $1 \& 2$.

This shows the market share performance differential of Cadbury Nigeria PLC and Nestle Nigeria PLC is shown in table 16 as pre-and post product Repackaging periods are compared, the table also shows the yearly growth rate of these two players of the food industry in Nigeria.

This is the test for relationship (strength of association) between the market share of the companies before and after the repackaging of products

The hypothesis was stated thus

$\mathbf{H}_{\mathbf{0}}$ : Re-packaging activities do not have significant impact on market share expansion.

$\mathbf{H}_{\mathrm{A}}$ : Re-packaging activities has significant impact on market share expansion

Decision rule: we accept the hypothesis as stated above if the analysis is positive but we reject the stated and adopt the alternative. In this case, the alternative is $\mathrm{H}_{\mathrm{A}}$.

Analysis is based on t-test statistics represented by the mathematical notation above.

The results are explained below

Table 4: t-test of the market share of Cadbury Nigeria Plc (before and after repackaging).

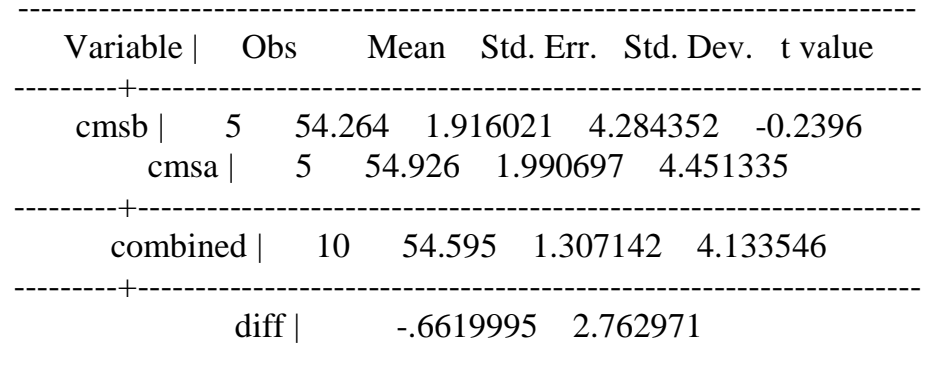

Source: Field data, 2016.

Table 4 shows the t-test result of market share volume of Cadbury Nigeria Plc pre-packaging and post packaging. The result showed that there was no significant relationship in the market share volume of Cadbury Nigeria Plc between their pre and post packaging periods both at 5\% and 10\% levels. This shows that even after the company carried out the repackaging of its products, it still had the same market share it had before the repackaging of products was done.

Table 5: t-test of the market share of Nestle Nigeria Plc (before and after repackaging).

Two-sample $t$ test with equal variances

$\begin{array}{clllll}\text { Variable | Obs } & \text { Mean } & \text { Std. Err. } & \text { Std. Dev. t value } \\ \text { nmsb | } & 5 & 34.136 & 1.867869 & 4.176682 & -0.4292 \\ \text { nmsa } & 5 & 35.268 & 1.861949 & 4.163444\end{array}$




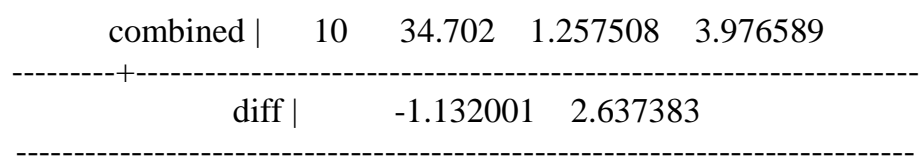

Source: Field data, 2016.

Table 5 shows the t-test result of market share volume of Nestle Nigeria Plc pre-packaging and post packaging. The results showed that there was no significant relationship in the market share volume of Nestle Nigeria Plc between their pre and post packaging periods both at 5\% and $10 \%$ levels. This shows that even after the company carried out the repackaging of its products, it still had the same market share it had before the repackaging of products was done.

Figure 1: graphical representation of the Market share Growth of Cadbury Nigeria Plc Pre-packaging and post-packaging periods.

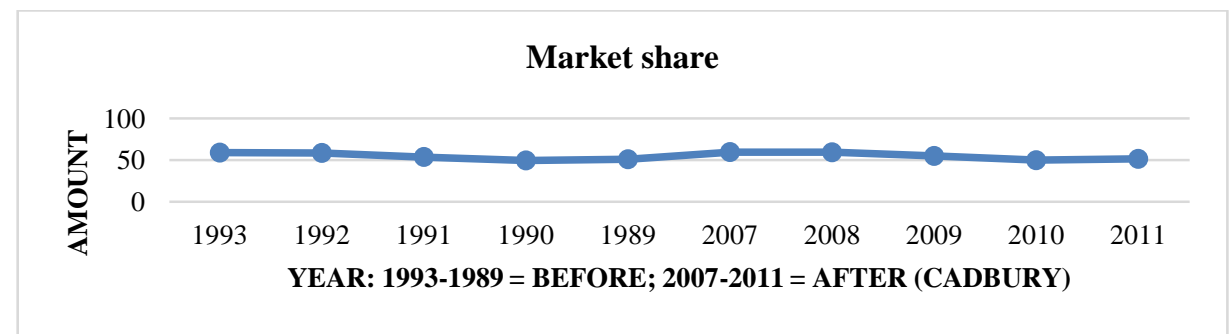

Source: Field data, 2016.

Figure 1 shows the graphical representation of the market share volume of Cadbury Nigeria Limited. From the Figure, we see that there was an increase in the market share volume of the company (Cadbury) from 1990 1993 when the re-packaging of products was done. After the repackaging was done, there was a slight increase then a steady fall in their market share volume not until 2010 when the company witnessed an increase in their market share volume.

Figure 2: Graphical representation of the Market share Growth of Nestle Nigeria Plc Pre-packaging and post-packaging periods.

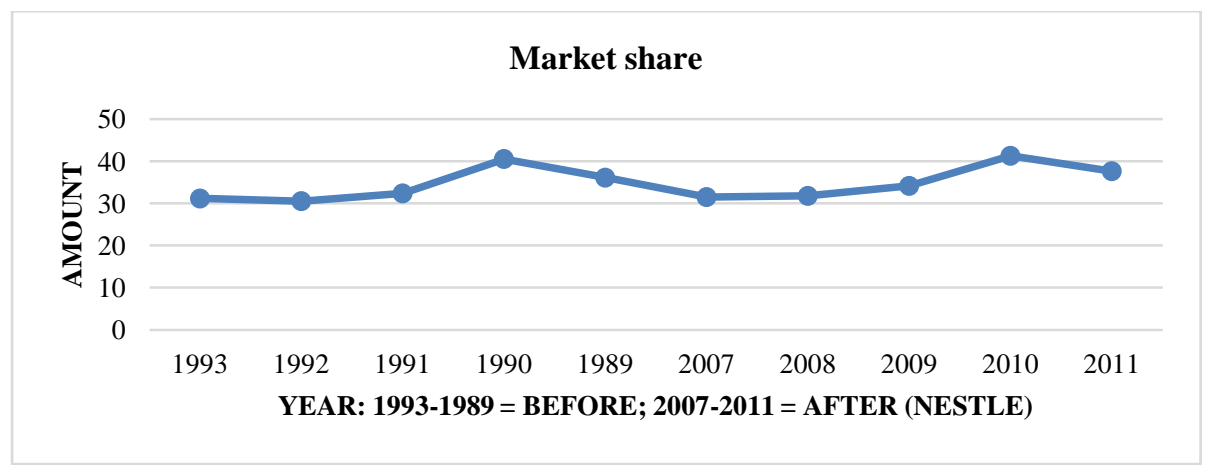

Source: Field data, 2016.

Figure 2 is the graphical representation of the market share volume of Nestle Nigeria limited. From the graph, we see that from 1990 there was a steady fall in the market share volume of the company. After repackaging of products was done in 2007, there was an increase in their market share volume from that year till 2010 and then a decrease in their market share volume. 
Figure 3: Graphical representation of the Market share Growth of Nestle Nigeria Plc Pre-packaging and post-packaging periods.

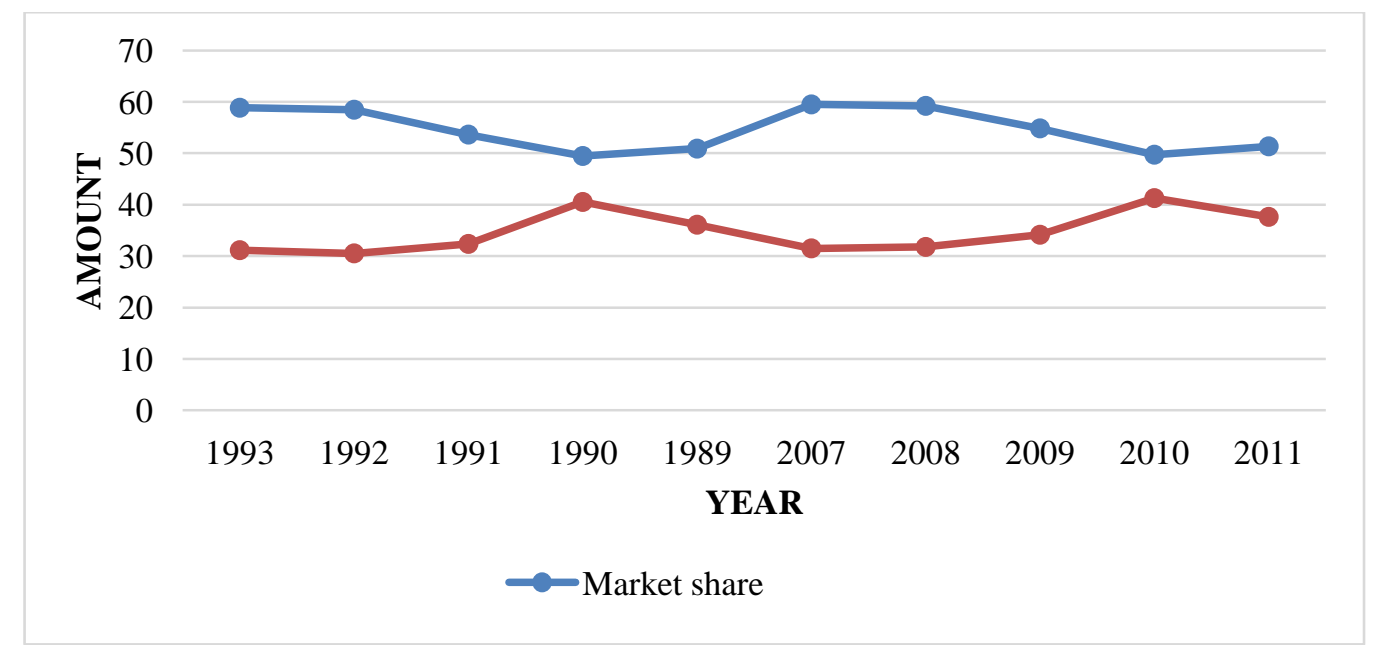

Source: Field data, 2016.

Figure 3 shows the market share volume of the two (2) companies under review. Here we noticed that Cadbury Nigeria Plc had a higher market share volume that Nestle Nigeria Plc both before and after the repackaging periods.

\section{CONCLUSION AND RECOMMMENDATIONS}

This study critically evaluated the impact of repackaging on the market share volume of some selected companies in Nigeria. Product repackaging is a very important marketing strategy to glamorize and modify a product in order to attract the customer's attention. Repackaging serves the interests of the manufacturers in the areas of product differentiation, market segmentation and branding. Packaging and repackaging of products help to eliminate adulteration of products and the fake products from the market. It was discovered in the course of this study that there was no significant relationship in the market share volume of the companies (Cadbury and Nestle Nigeria Limited) between their pre and post repackaging periods. It can therefore be stated that repackaging of products those not guarantee an increase in the market share volume of companies. Based on the findings of this study, we recommend that companies should expand the market by engaging in sales promotion to create awareness on their improved brands to get more customers which can result in larger market share volume. Repackaging of product should follow the trend of technological improvement and innovations.

\section{REFERENCES}

[1] Diana Twede (2005). "The Origins of Paper Based Packaging". Conference on Historical Marketing.

[2] Drucker, P.F., 1985. Innovation and Entrepreneurship. Butterworth-Heinemann, Oxford.

[3] Gurhan, G., Gunduz U., Kemal Kilic, \& Lutfihak Alpkanb (2013). Effects of innovation types on firm performance.Investopedia(2016):MarketShareDefinition;

[4] Kotler, P., 1991. Principles of Marketing. Prentice Hall, NJ. Lages L.F., Montgomery M.B. (2004). "Export performance as an antecedent of export commitment and marketing strategy adaptation: Evidence from small and medium-sized exporters", European Journal of Marketing, 38, (9), 1186-1214.

[5] Lewis, M. (1991), Understanding Brands, Kogan Page, London.

[6] Michael L, Kostas A, David F, Christian D. Zuniga, D, Wei, M O, Chris C, "Accurate 3DEMF mask model for full-chip simulation", in Optical Microlithography XXVI, Will Conley, Editors, Proceedings of SPIE Vol. 8683 (SPIE, Bellingham, WA 2013), 86831D.

[7] Mitul M. Deliya \& Mr. Bhavesh J. Parmar (2012). Role of packaging on consumer buying behaviorpatan. district. Global Journal of Management and Business Research 12 ( 10) 10-12

[8] Mohammad A.H, Wang A and Sunayya B (2012). Investigating on Tourists satisfaction: An empirical study on East Lake. European journal of business and management.4 (7)12-15

[9] OECD, 2005. Oslo Manual: Proposed Guidelines for Collecting and Interpreting Technological Innovation Data.

[10] Pilditch, James (1972), The Silent Salesman, Business Books Limited, London, UK. Sajuyigbe A.S, Ayanleke S.O and Ola O.S (2013).Impact of packaging on organizational sales turnover: a case study of 
Patterson Zoconist Cussons (pz) Plc, Nigeria. Interdisciplinary Journal Of Contemporary Research In Business. 4 (11), $497-508$.

[11] Shammot, M. M. (2011). Quality Management Practices and Their Impact on Organizational Performance, and Customer Behavior . European Journal of Economics, Finance and Administrative Sciences, 34 (8) 5-8p

[12] Soroka (2002) Fundamentals of Packaging Technology, Institute of Packaging Professionals Stewart, B. (1995), Packaging as an Effective Marketing Tool, Pira International Survey.

[13] Stewart, B (2004).Packaging design strategy. Pira International, Leatherhead Investopedia (2016): Market Share Definition; http://www.investopedia.com/terms/m/marketshare.asp\#ixzz4SnUvfokv 